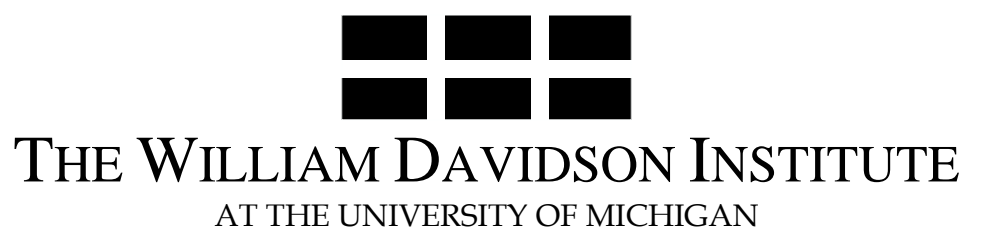

\title{
On the Role of Absorptive Capacity: FDI Matters to Growth
}

\author{
By: Yuko Kinishita and Chia-Hui Lu
}

William Davidson Institute Working Paper Number 845

August 2006 


\title{
On the Role of Absorptive Capacity: FDI Matters to Growth
}

\author{
Yuko Kinishita*
}

IMF
Chia-Hui Lu ${ }^{\dagger}$

Academia Sinica

August 2, 2006

\begin{abstract}
The paper studies the effects of foreign direct investment (FDI) on economic growth when sufficient provisions of infrastructure is a pre-requisite. In the overlapping generations structure setting, we show that technology spillovers via FDI take place only when the host country has the sufficient level of infrastructure. Infrastructure has a subsequent positive feedback on further investment which leads the country grow faster. If infrastructure falls short of the critical level, however, then FDI has little effect on growth as the country is trapped in a low-growth equilibrium. We also present the simulations and empirical results based on panel data for 42 developing countries between 1970 and 2000. They provide support to the model that FDI and infrastructure are complements in affecting per capita GDP growth.
\end{abstract}

Keywords: foreign direct investment; economic growth, technology diffusion, infrastructure

JEL Codes: F21, O40, O33, H54

\footnotetext{
*E-mail: ykinoshita@imf.org

† E-mail: clu@econ.sinica.edu.tw
} 


\section{Introduction}

Acquiring advanced technology and superior managerial know-how embodied in foreign direct investment is one of the most important reasons why countries offer various incentives to woo the establishment of subsidiaries of multinational firms in its territory. Empirical evidence supporting this argument, however, is far from being settled. ${ }^{1}$ Many argue that the lack of consensus on positive spillovers from FDI is due to the differences in the host country's absorptive capacity such as human capital, financial market development, trade openness and institutional quality: the positive effects of FDI can be found only when it is conditioned on the recipient's absorptive capacity.

In this paper, we identify sufficient infrastructure as the host country's absorptive capacity. We argue that good infrastructure is not only the driver of FDI inflows but also a pre-requisite for positive spillovers from FDI on the host country economy. We present a overlapping generation model in which the degree of technology spillovers is determined by FDI inflows to the host country and a technology gap from the leading country, conditional on the country's infrastructure level. If it falls short of a threshold, the country stagnates even when there are a room for technology catch-up and there are some FDI inflows. On the other hand, if the country's infrastructure is sufficiently large, the country will benefit spillovers from FDI and attain the higher level of growth. As a consequence, the country is able to invest more in infrastructure that further attracts more FDI and leads to even faster growth.

Sufficient provisions of infrastructure can help attract FDI as it improves the investment climate in developing countries by lowering the cost of foreign investment and raising the rate of return. Infrastructure is, among other attributes such as market size, labor costs, and political and social stability, one of the main factors that influence FDI decisions in emerging markets. For instance, perceived weak infrastructure in India is often cited as a reason why investors are turning towards other investment destinations. ${ }^{2}$ Being aware of infrastructure bottleneck for further

\footnotetext{
${ }^{1}$ For example, firm-level studies by Aitken and Harrison (1999) and Haddad and Harrison (1993) find no evidence of positive spillovers from FDI to local firms.

${ }^{2}$ AT Kerney's survey on the FDI confidence index shows that India is lagging behind in infrastructure
} 
development, India has recently announced its plan to set up a $\$ 5$-billion infrastructure development fund to facilitate the establishment of large special economic zones (SEZs) in Mumbai. ${ }^{3}$ Also, in China, inland province such as Sichuan has been spending heavily on bridges, expressways, and power plants in order to replicate the development success led by foreign investment in coastal provinces. Due to a shortening of transit time after the opening of a new road, Sichuan province pulled in more than $\$ 6$ billion of FDI and grew by 12.7 percent in $2005 .{ }^{4}$

Figure 1 presents a casual observation on the complementarity between FDI and infrastructure. The figures are computed from the data on forty-two developing countries between 1970 and 2000. Each bar represents the average per capita GDP growth rate in each of the nine groups according to the ratio of FDI to GDP and the level of infrastructure, where infrastructure is measured by the number of main telephone lines in a country (Barro, 1989) ${ }^{5}$. Given the level of infrastructure - low, medium, and high-, we observe that the higher is per capita GDP growth rate on average, the more FDI the country receives. This tendency is the most obvious where the level of infrastructure is high.

The paper is organized as follows. Section 2 presents a brief overview of the literature and Section 3 presents a overlapping generation model to explain the mechanism through which infrastructure and FDI interact with the extent of technology spillovers, being followed by numerical simulations of the model in Section 4. Section 5 provides the empirical analysis using the panel data on forty-two developing countries between 1970 and 2000. Section 6 concludes the paper.

in a group of large emerging countries (Brazil, China, Mexico, and Poland). (ATKerney, FDI Confidence Index, Sept 2003, Volume 6).

${ }^{3}$ The Hindu "Poor Infrastructure a major hurdle: U.S. CEOs" (June 2, 2006). Hulten and others (2003) find that there are indeed significant and positive infrastructure externalities in India.

${ }^{4}$ Dexter Roberts, "Go West, Westerners" (Business Week, November 13, 2005).

${ }^{5}$ Infrastructure is also measured by the length of roads and power generations, which show qualitatively similar results. 


\section{Brief Overview of the Literature}

The role of FDI as a carrier of foreign technology had been long recognized in the theoretical literature. A pioneering work by Findlay (1978) develops a theoretical framework and hypothesizes that the rate of technology transfer from FDI is positively related to technology gap between the host country and the source country. In this model, technology spillover inevitably happens as long as the host country's technology level is relatively behind that of the source country. In other words, there is no room for the host country's absorptive capacity to play a role in affecting the extent of technology spillovers.

The empirical evidence for technology spillover from multinational to domestic firms, however, is still divided. At the disaggregate level, Aitken and Harrison (1999) find no evidence of positive spillovers from foreign to local Venezuelan firms. Kokko and others (1996) study Uruguayan manufacturing plants to explore the hypothesis of technology spillovers. They find a positive spillover effect only in the sub-sample of locally-owned plants with moderate technological gap vis-a-vis foreign firms. The validity of their results, however, suffers from critics of exogenous sample-splitting and the omitted variable bias such as the host country's absorptive capacity. Kinoshita (2002) includes R\&D expenditure as a proxy for absorptive capacity in the study of Czech manufacturing firms and finds that the degree of spillover from FDI is positively related to the host country's R\&D expenditure.

In cross-country studies, Borensztein and others (1998) find that the incidence of technology spillover via FDI hinges on the level of human capital. Without educated workforce, however, FDI has no effect on economic growth. Their study is one of the first studies to take into account the role of absorptive capacity. Other authors refer to, among other things, financial development, trade openness, and institutional quality as absorptive capacity. Alfaro and others (2004) condition the effect of FDI on growth on the development of financial markets and found that FDI has accelerated growth for a group of countries with more developed financial markets. Balasubramanyam and others (1996) and Kohpaiboon (2002) argue that trade openness is crucial for a positive growth effect of FDI. More recently, Durham 
(2004) examines institutional and financial development ${ }^{6}$ as absorptive capacity that determines the degree of technology spillovers. All these recent studies explore the role of absorptive capacity but do not explicitly take into account a technology gap as in Findlay. On the other hand, Girma (2005) muddles with the concepts of technology gap and absorptive capacity and concludes that technology transfer occurs if the host country's "absorptive capacity" is moderate. However, what she calls absorptive capacity is close to the notion of technology gap, or the catch-up effect.

In this study, we distinguish two concepts, absorptive capacity and technology gap. Absorptive capacity is the ability necessary for the host country to absorb and adopt new incoming technology from a foreign country. Technology gap is a distance between the host and source countries' technology levels, which is exogenously given. Our model is thus an extension of Findlay's by further endogenizing the role of absorptive capacity in determining the degree of technology spillovers.

More explicitly, the host country's absorptive capacity is proxied by infrastructure in the model. There are two channels via which infrastructure could affect growth. First, it is well-known that infrastructure is one of the important determinants of economic growth ${ }^{7}$ in various cross-country studies as infrastructure exerts positive externalities economy-wide (e.g. the more telephone mainlines increase efficiency of communication). Second, foreign investors are likely to be attracted to a country with sufficient provisions of infrastructure which reduces the cost of doing business as many empirical studies corroborate (Wheeler and Mody 1992; Kumar 2001; Campos and Kinoshita, 2003). In other words, infrastructure affects growth not only via a direct channel but also via an indirect channel through FDI. This second effect can be non-negligible as it has a compounding effect: infrastructure first increases the efficiency of FDI and FDI together with high quality infrastructure affects growth positively. Therefore, infrastructure is akin to the notion of absorptive

\footnotetext{
${ }^{6}$ The variables used for absorptive capacity are stock market capitalization, business regulation, property rights, and corruption indexes.

${ }^{7}$ Aschauer,1989; Munnel, 1990; Easterley and Rebelo, 1993; Hulten, Gramlich, 1994; Peteira and Flores de Frutos, 1999; Canning and Pedroni, 1999; Bougheas et al, 1999.
} 
capacity. There are also other possible factors that could explain the absorptive capacity. In the empirical section, we will test other variables that could proxy the absorptive capacity to see if infrastructure is indeed an appropriate measure of the absorptive capacity.

\section{The Model}

We develop an overlapping generations model to explain the structure of the host economy. There are two types of individuals in each period, young and old. Each individual lives for two periods. Suppose that $L_{t}$ individuals are born in period $t$, and population grows at rate $n$; thus $L_{t}=(1+n) L_{t-1}=(1+n)^{t}$ given that $L_{0}$ is normalized to unity. Since individuals live for two period, at time $t$, there are $L_{t}=(1+n)^{t}$ people in their first period of lives and $(1+n)^{t-1}$ individuals in their second period of lives.

Let $c_{1 t}$ and $c_{2 t}$ be the consumption in period $t$ of young and old individuals; the utility of an individual born at $t$, denoted by $U_{t}$, is defined as:

$$
U_{t}=\ln c_{1 t}+\beta \ln c_{2 t+1},
$$

where $\beta>0$ reflects the individual's subject time preference rate; if $\beta<1$, individual puts greater weight on first-period than second-period consumption; if $\beta>1$, the situation is reverse.

When young, an individual works and earns labor income. She saves a fraction of income for the consumption when old. Also, the young also pays taxes, which finances public investment in infrastructure. Suppose young individual supplies one unit of labor inelastically and earns wage $w_{1 t}$, which is determined endogenously as will be more clear later. The individual pays income tax at a fixed rate denoted by $\tau$ and then divides the dispensable labor income into first-period consumption and savings; hen the individual gets old, he or she simply consumes the savings and any interests earned. The lifetime budget constraint faces each individual is

$$
c_{1 t}+\frac{c_{2 t+1}}{1+r_{t}}=(1-\tau) w_{1 t}
$$


The left-hand side of (2) denotes the present value of lifetime consumption which should equal to the present value of lifetime income, shown in the right-hand side of (2). The optimal consumption path $\left(c_{1 t}, c_{2 t+1}\right)$, solved by maximizing (1) subject to $(2)$, is shown in terms of wage, tax rate, interest rate, and time preference rate as:

$$
\begin{aligned}
c_{1 t} & =\frac{(1-\tau) w_{1 t}}{1+\beta} \\
c_{2 t+1} & =\frac{\beta(1+r)(1-\tau) w_{1 t}}{1+\beta}
\end{aligned}
$$

Income tax revenues are used to finance the expense of infrastructure. In each period, the government runs a balanced budget: collects taxes and spends all tax revenue to invest in infrastructure. Therefore the infrastructure per active labor is $s_{t}=\tau w_{1 t}$.

\section{Production}

In the production function, there are two factors of production: capital and labor. Labor $\left(L_{t}\right)$ is supplied entirely by domestic residents (the young). For simplicity, capital $\left(K_{t}\right)$ is entirely provided by foreign investors. In each period, capital depreciates completely. Foreign capital flows in till the net marginal product of capital (marginal product of capital minus depreciation rate) equals to the world interest rate $r^{W}$.

Let production technology is represented by the Cobb-Douglas function and is denoted by $Y_{t}=A_{t} F\left(K_{t}, L_{t}\right)=A_{t} K_{t}^{\alpha} L_{t}^{1-\alpha}$, where $A_{t}$ denotes the technology parameter. We assume that domestic technology progress is driven by the potential technology spillover from foreign direct investment. Specifically, we let

$$
A_{t+1}=A_{t}+\left(A_{t}^{W}-A_{t}\right) \phi\left(k_{t}\right) h\left(s_{t}\right),
$$

where $A_{t}^{W}$ denotes the foreign technology (the world's technology frontier), which is embodied in foreign capital, and is assumed to grow at a constant exogenous rate $g ;\left(A_{t}^{W}-A_{t}\right)$ denotes the technology gap between the home and foreign countries 
(similar to the concept of the relative backwardness in Findlay 1977); $\phi\left(k_{t}\right)$ measures the effective exposure to foreign capital, where $k_{t} \equiv \frac{K_{t-1}}{L_{t-1}}$ is the ration of foreign capital to domestic labor. Specifically, let

$$
\phi\left(k_{t}\right)=1-\frac{1}{\exp \left\{k_{t}\right\}}
$$

where $\phi(0)=0, \phi(\infty)=1, \phi^{\prime}()>0$, and $\phi^{\prime \prime}()<0$, which implies that the presence of foreign capital is the necessary condition for spill over, and extent of technology leakage is increasing in the $k_{t}$, but the marginal rate of technology spill over is diminishing. Finally, $h\left(s_{t}\right)$ is defined as

$$
h\left(s_{t}\right)=\left\{\begin{array}{ll}
0, & \text { if } s_{t}<\underline{s} \\
1-\frac{1}{\exp \left\{s_{t}-\underline{s}\right\}}, & \text { if } s_{t} \geq \underline{s}
\end{array},\right.
$$

where $\underline{s}$ denotes the minimum level of infrastructure that the home country needs to acquire, so that the effect of "spillover" starts kicking in. We normalize $A_{0}^{W}$ to unity; hence $A_{t}^{W}=(1+g) A_{t-1}^{W}=(1+g)^{t}$, and domestic technology progress equation becomes:

$$
A_{t+1}= \begin{cases}A_{t} & \text { if } s_{t}<\underline{s} \\ A_{t}+\left((1+g)^{t}-A_{t}\right)\left(1-\frac{1}{\exp \left\{k_{t}\right\}}\right)\left(1-\frac{1}{\exp \left\{s_{t}-\underline{s}\right\}}\right) & \text { otherwise }\end{cases}
$$

Notice that the technology parameter $A_{t}$ is a state variable and is endogenously determined in previous period. The return rate of capital provided in the world market, denoted by $r^{W}$, for simplicity, is exogenously given and is assumed to be constant over time.

\section{Equilibrium Conditions}

Markets are assumed to be competitive, labor and capital thus earn their marginal products, and firms earn zero profits. In each period, in the absence of investment frictions (such as taxes or subsidies), foreign capital flows in until the marginal product of capital equals to $r^{W}+1$. In turn, other endogenous variables $\left\{k_{t}, w_{t}, s_{t}, c_{1 t}, c_{2 t+1}\right\}$ 
can be solved as:

$$
\begin{aligned}
k_{t} & \equiv \frac{K_{t}}{L_{t}}=A_{t}^{\frac{1}{1-\alpha}}\left(\frac{\alpha}{1+r^{W}}\right)^{\frac{1}{1-\alpha}} \\
w_{t} & =(1-\alpha) A_{t}^{\frac{1}{1-\alpha}}\left(\frac{\alpha}{1+r^{W}}\right)^{\frac{\alpha}{1-\alpha}} \\
s_{t} & =\tau(1-\alpha) A_{t}^{\frac{1}{1-\alpha}}\left(\frac{\alpha}{1+r^{W}}\right)^{\frac{\alpha}{1-\alpha}} \\
c_{1 t} & =\frac{(1-\tau)(1-\alpha) A_{t}^{\frac{1}{1-\alpha}}\left(\frac{\alpha}{1+r^{W}}\right)^{\frac{\alpha}{1-\alpha}}}{1+\beta} \\
c_{2 t+1} & =\frac{\beta\left(1+r^{W}\right)(1-\tau)(1-\alpha) A_{t}^{\frac{1}{1-\alpha}}\left(\frac{\alpha}{1+r^{W}}\right)^{\frac{\alpha}{1-\alpha}}}{1+\beta}
\end{aligned}
$$

Then plugging the solved $k_{t}$ and $s_{t}$ into (8), we can solve $A_{t+1}$, which then determine $\left\{k_{t+1}, w_{t+1}, s_{t+1}, c_{1 t+1}, c_{2 t+2}\right\}$. Therefore, given any country's initial condition regarding $\left\{A_{0}, r^{W}, \alpha, \underline{s}, g, n\right\}$, by iteration, we can solve the transition path from the initial status to steady state of the economy.

We emphasis the role of absorptive capacity in determining the extent of technology spillover through FDI, which consequently affects the host country's growth. The following equation explicitly shows the linkage:

$$
Y_{t}=A_{t} k_{t}^{\alpha} L_{t}=A_{t}^{\frac{2-\alpha}{1-\alpha}}\left(\frac{\alpha}{1+r^{W}}\right)^{\frac{1}{1-\alpha}}(1+n)^{t}
$$

Taking logarithm on both sides, we have:

$$
\begin{aligned}
& \ln Y_{t}=\left(\frac{2-\alpha}{1-\alpha}\right) \ln A_{t}+\frac{1}{1-\alpha} \ln \left(\frac{\alpha}{1+r^{W}}\right)+t \ln (1+n) \\
\ln \frac{Y_{t+1}}{Y_{t}}= & \left(\frac{2-\alpha}{1-\alpha}\right) \ln \frac{A_{t+1}}{A_{t}}+\ln (1+n) \\
\simeq & \left(\frac{2-\alpha}{1-\alpha}\right)\left(\frac{A_{t}^{W}-A_{t}}{A_{t}}\right) \times\left(1-\frac{1}{\exp \left\{k_{t}\right\}}\right) \times\left(1-\frac{1}{\exp \left\{s_{t}-\underline{s}\right\}}\right) \times I\left(s_{t} \geq \underline{s}\right) \\
& +\ln (1+n)
\end{aligned}
$$




\section{Simulations}

We demonstrate here that the extent to which an FDI host country can catch up to the world frontier technology embodied in FDI crucially depends on the country's infrastructure. For simplicity, we assume that infrastructure is financed by income tax collected by the government. We choose exogenous parameters $\left\{r^{W}=0.06\right.$, $\alpha=0.3, \underline{s}=0.01, g=0.05, n=0.01, \beta=0.5\}$ and initial values for the state variables $\left\{A_{0}=0.9, A_{0}^{W}=1, L_{0}=1\right\}$.

Under different tax policies $\{\tau=0.01, \tau=0.03, \tau=0.05\}$, we study the evolution path of a country's labor income, consumption, foreign capital inflow, infrastructure, and technology gap as presented in Figure 2. It is shown that when the tax rate is low, $\tau=0.01$, the host country's initial infrastructure is below the threshold $\left(s_{0}=0.0035<\underline{s}=0.01\right)$. Although some advanced foreign technology is introduced into a host country due to the relative high return to capital, a spillover effect is inhibited since the host country processes insufficient absorptive capacity. The country thus stagnates as its technology remains at the initial level and the technological gap with the world is widening over time. As a result, per capita consumption of the old as well as the young, output, and foreign capital per worker remain constant.

When the tax rates are sufficiently high, $\tau=0.03$, or $\tau=0.05$, the host country's initial infrastructure level, which are 0.010 and 0.017 respectively, exceeds the threshold. As foreign capital flows in, and the effect of technology spillovers kick in, and the country's growth starts to take off. The country may initially attract only a small amount of foreign capital due to its low technology level. As the country climbs up the technological ladder, however, it enhances its attractiveness to foreign capital and an increase in national income further improves the infrastructure level. As technology spillovers interacted with the absorptive capacity are amplified, the speed of a catch-up accelerates, increases the return to FDI and attracts more foreign capital inflows. Eventually, the technology gap between the host country and the world closes up. The country with $\tau=0.05$ converges to the frontier technology faster than the country with $\tau=0.03$ but at the expense of a lower consumption 
level in the early time. ${ }^{8}$ In steady state, per capita output grows at the same rate as the world technology grows.

\section{Empirical Analysis}

The theoretical model presented in the previous section shows that the absorptive capacity is crucial in explaining the effect of FDI on economic growth. In this section, we test this hypothesis by using panel data from 42 developing countries for the periods of 30 years.

\section{$5.1 \quad$ Data}

The data used in this study comprise a panel of 42 non-OECD countries ${ }^{9}$ for the period of 30 years that covers 1971 and 2000. The growth rate of income, initial income and government consumption are drawn from Penn World Table 6.1. Schooling is measured as average years of secondary schooling in the working population from the Barro and Lee dataset. Population growth and black market premium are taken from the World Development Indicators. Infrastructure variables (telephone lines, roads, and energy consumption) are drawn from the infrastructure data set constructed by Calderon and Serven, available on the World Bank website. The FDI variable refers to gross FDI inflows drawn from IMF 's International Financial Statistics. In the regression, the presence of foreign knowledge in the country is captured by a ratio of FDI inflows to GDP. The existing empirical literature on economic growth uses the cross-sectional framework by taking the average of a certain time span (e.g. five years, ten years, or longer) in order to smooth out the business cycle parts of the series [Barro, 1991]. Following the existing studies, we construct a panel data set with data averaged over each of the six 5-year periods between

\footnotetext{
${ }^{8}$ It is plausible that there exists an optimal taxation path that maximizes the aggregate utilities of the infinite number of generations. The further study is required to see how different the taxation schedule may be from our model when individuals are allowed to choose between labor and leisure, or when the infrastructure is financed by tax on foreign capital.

${ }^{9}$ It includes emerging and developing countries but does not include transition countries. See the list of the countries in Appendix.
} 
1971 and 2000. The use of the 5 year-period panel data has an advantage over the 30-year cross sectional data as it provides us with greater number of observations and allows us to control for heterogeneity across countries.

\subsection{Methodology}

Combining equations (8) and (10), our empirical specification in a reduced form is as follows:

$\ln \left(\frac{Y_{i t}}{Y_{i t-1}}\right)=\beta_{1} \ln Y_{i 0}+\beta_{2} F D I_{i t}+\beta_{3} A B_{i t}+\beta_{4} F D I_{i t} \times A B_{i t} \times C a t c h u p_{i t}+\beta_{5} n_{i t}+\beta_{6} X_{i t}+u_{i t}(15)$

where $Y_{i 0}$ is initial income level, $F D I_{i t}$ is a ratio of gross FDI inflows to GDP, $A B_{i t}$ is a proxy for absorptive capacity (i.e. infrastructure), Catchup $i t$ is a gap between output in the leading country and that of country $i, n_{i t}$ is a population growth, and $X_{i t}$ is a set of other variables that affect growth rates.

\subsection{Estimation Results}

We attempt to re-examine the effect of FDI on growth based on our theoretical model. First, we see whether or not FDI has a positive effect without conditioning on the absorptive capacity. Second, we will see if FDI interacts with the absorptive capacity to affect growth.

Table 1 presents the base regression results for developing countries. All regressions include the conventional growth determinants such as the initial level of income, government consumption, population growth, black market premiums following the neoclassical growth studies. The variables of our interest are FDI and the interaction terms with FDI and infrastructure. In addition to FDI and infrastructure, we also include the schooling or human capital variable. It is generally accepted in the literature that human capital is one of the most important determining factors for economic growth. At the same time, human capital could also reflect a FDI- recipient country's absorptive capacity as argued by Borensztein, DeGregorio, and Lee (1998).

Table 1 shows that FDI does not exert a positive impact on growth as shown in 
a negative but statistically insignificant coefficient of FDI in most columns. In the OLS regressions, initial income and average years of schooling enter significantly with expected signs. Turning to human capital-related variables, the interaction term between FDI and schooling enter negatively in contrast to the finding by Borenstein and others (1998). This suggests that the effect of FDI on growth is not necessarily conditional on educational attainment. On the other hand, the coefficient of the interaction term between FDI and infrastructure is positive and significant. This implies that FDI affects growth rate positively only when there is already sufficient infrastructure in place in the recipient country. Furthermore, infrastructure itself exerts a positive effect on economic growth by lesser magnitude than human capital.

Columns 3 through 6 show the panel regression results. The findings in the OLS regressions appear to be preserved in the panel regressions. Random effects GLS estimates are quite similar to those in the OLS in size and magnitude. As we move to the fixed effects "within" estimators, the coefficients become somewhat fragile. Namely, the negative effect of FDI is greater and statistically significant. However, the Hausman test cannot reject the random-effect model (column 3) over the fixed-effect model (column 4). So we will interpret the within estimators with caution.

For comparison, we also present the between estimator and a normal maximum likelihood estimator in the table. The between estimator is equivalent to a crosssectional regression over 30 years. Interestingly, the long-run effect of FDI is positive but not statistically significant. Nevertheless, the compounding effect of FDI and infrastructure is present and three times as much as in the panel with a shorter interval.

To sum up, we find that FDI alone fails to affect economic growth as found in other previous studies. We also find that the positive effect of FDI is realized in the country only when there is sufficient infrastructure. This result is robust even after controlling for a possible interactive effect between FDI and schooling.

Table 2 presents our robustness checks. In Table 2 we check whether or not our choice of infrastructure variable affects our results. We substitute the number of telephone main lines per 1000 workers used in the base regressions with a number 
of measures available in the dataset for the infrastructure variable. There are two alternative infrastructure variables in Calderon and Serven: power generation capacity (GW per 1000 workers) and total roads length in km per sq. of surface area. We also constructed the composite infrastructure index "principle component" from all three variables by principle component methods. We find that two of the three yield a positive coefficient on the interaction term between FDI and infrastructure. The sign is opposite when we use total roads length, although it is statistically insignificant. This may be due to measurement errors in the road variable. The road variable is also least correlated with the composite infrastructure index.

In Table 3, we check whether our results are sensitive to the omission of other variables that could measure absorptive capacity such as trade openness, quality of institutions, and financial market development. The regressions are based on random-effects GLS. We find that our results are robust to the inclusion of other variables. It is generally accepted that trade openness is a crucial factor in accelerating economic growth as seen in the Asian tigers. At the same time, it is often argued that FDI and trade are complements particularly when FDI is exportpromoting. We add trade openness measured as the sum of exports and imports as a share of GDP and the interaction of FDI and openness. The inclusion of these variables in column 1 does not affect the base results of a positive and significant coefficient of FDI*infrastructure. In columns 2-4, we add the institutional quality variables: rule of law, corruption, and quality of bureaucracy that are drawn from ICRG. Again, the interaction term between FDI and infrastructure remain positive and significant. This finding contrasts those by Durham (2004). Using a different dataset that cover both developed and developing countries, Durham finds that the effect of equity foreign direct investment has a positive effect conditional on the institutional quality such as property rights and regulation indices. Once we include infrastructure in the panel data setting, we find a different result. Finally, in columns 5-7, we include the financial market development indicators: liquidity liabilities as a share of GDP, private credit by deposit money banks and other financial institutions as a share of GDP, stock market capitalization as a share of GDP. They are drawn from the World Bank's Structure Data. Our results on FDI and infrastructure remain robust through different specifications. As Alfaro and others (2004) 
argue, well-developed financial markets could lead to significant gains from FDI as also found in the positive coefficients of some of the interaction terms between FDI and liquidity liabilities/stock market capitalization in our results. However, they fail to bear statistical significance.

In Tables1-3, we show that there is a positive interactive effect between FDI and infrastructure. This is also because FDI is likely to be drawn to a country with sufficient infrastructure to start with. In Table 4, we introduce the catch-up term to see if the results still hold. The catch-up term for country $i$ is defined as $\frac{Y_{\max }}{Y_{i}}$, the ratio of output level of the leading country's to that of country $i$ 's. The greater the catch-up term is, the more room for country i to adopt the existing technology already produced in the country on the technology frontier. If the so-called catchup effect is indeed present, then the laggard country would benefit from exogenous technology spillovers from the leader for simply being behind on the technology level and the technology gap will automatically disappear over time. In that case, we would expect the catch-up term to have a positive impact on growth. This is also closely related to the concept of convergence to the leading country.

We include in column 1 the interaction term of FDI and catch-up to see if FDI facilitates the adoption and implementation of new technology from the leading country. For developing countries, this variable shows more explicitly whether or not the presence of foreign investment in a country magnifies the catch-up effect from technology diffusion from abroad. The answer is no. The interaction term of FDI and catch-up enters negatively but insignificantly, indicating that FDI does not necessarily facilitate the process of catch-up.

Column 2 shows that the catch-up effect via FDI reappears once we control for the level of infrastructure as shown in the positive coefficient of the interaction between FDI, catch-up and infrastructure. This implies that technology spillovers from FDI for laggard countries are only present when a country has sufficient infrastructure. This result is robust to the inclusions of other variables (Columns 3 and 4). Note that there also exists a pure catch-up effect, or convergence to the leading country as indicated in a positive coefficient of $\frac{Y_{\max }}{Y_{i}}$. This is further strengthened in presence of infrastructure and FDI. Tables 1-3 presented that FDI and infrastructure together have a positive and significant effect on growth. Table 4 confirms that 
such a compounding effect of FDI and infrastructure takes a particular channel of technology diffusion as shown in the interaction term with the catch-up term.

\subsection{Endogeneity}

One important concern in assessing the effect of FDI on growth is the possibility of endogeneity and reverse causality of FDI. If a fast growing economy requires more FDI, then FDI and growth are simultaneously determined and FDI would be correlated with an error term. Alternatively, there may be omitted variable bias as we are using a reduced-form estimation applied to developing countries. If omitted variables are observable and readily available, we can include them as additional regressors. However, if omitted variables are unobservable, we will end up with a biased estimate for the coefficient of FDI. Thus, we will need to construct instruments for FDI.

Tables 5 and 6 report the results of generalized two-stage least square (G2SLS) and error-component two-stage least square (EC2SLS), respectively. ${ }^{10}$ Instrumental variables for FDI are one-year lagged FDI, corruption, bureaucracy, law, and log of population. The F-test for the joint significance of the instruments in all cases is above 10, suggesting that there is no weak instruments problem. The Hausman test shows that the coefficients in the Within 2SLS (W2SLS) and EC2SLS are not systematically different. Thus, we do not report the results from W2SLS here.

Comparing Column 3 in Table 1, the results of the instrumental variable estimation in Table 5 are similar results to those obtained by GLS. The coefficients on FDI and other interaction terms with FDI show a similar pattern, though they are somewhat exaggerated in Table 5. In particular, the interaction term between FDI and infrastructure is 5.05 which is three times as large as that in GLS (Column 2, Table 5). The IV estimation also indicates that FDI and infrastructure are complementary in affecting growth as before. Similarly, the IV estimation in Table 6 clearly yield the similar pattern to the results in Table 4 . The catch-up effect is present as shown in the positive coefficient on $\frac{Y_{\max }}{Y_{i}}$. However, a negative coefficient

\footnotetext{
${ }^{10}$ G2SLS and EC2SLS yield the same asymptotic variance-covariance matrix (Baltagi and Lin, 1992). See Chapter 7 in Baltagi (2005) for more detail.
} 
of FDI interacted with the catch-up term shows that the process of catch-up is not necessarily accelerated by the presence of foreign knowledge in the country. Rather, the positive catch-up effect kicks in only when the country has sufficient absorptive capacity (e.g. infrastructure) and receives FDI, as shown in the positive coefficient of the interaction term among FDI, infrastructure, and the catch-up term.

\section{Conclusions}

This paper has studied the importance of absorptive capacity in determining the effect of FDI on economic growth. We highlight the role of infrastructure as one of the most important conduits or constraints for enhancing the efficiency of FDI. In the overlapping generation model, we show that the degree of technology spillovers is determined by FDI inflows to the host country and a technology gap from the leading country, conditional on the country's infrastructure level. If it falls short of a threshold, the country stagnates even when there are some FDI inflows and a room for technology catch-up. On the other hand, if the country's infrastructure is sufficiently high, the country will benefit spillovers from FDI and attain the higher level of growth.

Our paper contributes to the FDI-growth literature by confirming that FDI is indeed an important channel of international technology diffusion once we take into account the host country's absorptive capacity. We also distinguished three factors that influence the degree of technology spillovers - relative backwardness (initial technology gap), FDI intensity, and absorptive capacity in the empirical analysis to affirm the complementarity among these factors. More importantly, the main finding of this paper suggests that FDI alone is not a panacea for economic development; the host country should undertake infrastructure investment prior to attracting FDI in order to maximize the incidence of technology spillovers from FDI.

The finding leads to the policy implication that infrastructure development should be an integral part of growth strategy especially when a country is opening up for foreign investment. In developing countries, public investment can provide physical infrastructure prior to attracting FDI.

Despite further infrastructure needs, the share of infrastructure investment fi- 
nanced by the public sector has been on a declining trend during the last three decades in a number of developing countries. ${ }^{11}$ In the countries that face tight fiscal deficit limits because of fiscal adjustments or institutional constraints, ${ }^{12}$ the increasing involvement of the private sector is needed in building physical infrastructure. Other alternative to public investment is public-private partnerships (PPPs). Attracting FDI in the key infrastructure sectors such as telecommunication, energy, and transport could also substitute public financing to support increased infrastructure investment without adding to direct government borrowing and help create a vicious cycle of foreign investment inflows in other sectors.

\footnotetext{
${ }^{11}$ See the IMF board paper on Public Investment and Fiscal Policy (SM/04/93) for more detail.

${ }^{12}$ For example, the member countries of the EU under the Stability and Growth Pact cannot borrow to finance additional public investment beyond the limit.
} 


\section{Appendix}

\section{List of the Countries}

$\begin{array}{llllll}\text { Bangladesh } & \text { BGD } & \text { Israel } & \text { ISR } & \text { Senegal } & \text { SEN } \\ \text { Bolivia } & \text { BOL } & \text { Jamaica } & \text { JAM } & \text { Singapore } & \text { SGP } \\ \text { Brazil } & \text { BRA } & \text { Jordan } & \text { JOR } & \text { Sierra Leone } & \text { SLE } \\ \text { Chile } & \text { CHL } & \text { Kenya } & \text { KEN } & \text { El Salvador } & \text { SLV } \\ \text { China } & \text { CHN } & \text { Korea } & \text { KOR } & \text { Thailand } & \text { THA } \\ \text { Columbia } & \text { COL } & \text { Sri Lanka } & \text { LKA } & \text { Tunisia } & \text { TUN } \\ \text { Costa Rica } & \text { CRI } & \text { Mexico } & \text { MEX } & \text { Turkey } & \text { TUR } \\ \text { Egypt } & \text { EGY } & \text { Mali } & \text { MLI } & \text { Mauritius } & \text { MUS } \\ \text { Ghana } & \text { GHA } & \text { Malaysia } & \text { MYS } & \text { Uganda } & \text { UGA } \\ \text { Guatemala } & \text { GTM } & \text { Nicaragua } & \text { NIC } & \text { Uruguay } & \text { URY } \\ \text { Honduras } & \text { HND } & \text { Pakistan } & \text { PAK } & \text { Venezuela } & \text { VEN } \\ \text { Indonesia } & \text { IDN } & \text { Panama } & \text { PAN } & \text { South Africa } & \text { ZAF } \\ \text { India } & \text { IND } & \text { Peru } & \text { PER } & \text { Paraguay } & \text { PRY } \\ \text { Iran } & \text { IRN } & \text { Rwanda } & \text { RWA } & \text { Zambia } & \text { ZMB }\end{array}$




\section{References}

[1] Aghion, P., D. Comin, And P. Howitt (2006), "Why does domestic saving matter for Economic Growth?," NBER Working Paper 12275.

[2] Alfaro, L, A.Chanda, S. Kalemli-Ozcan and S. Sayek (2004), "FDI and Economic Growth: The Role of Local Financial Markets," Journal of International Economics, 64(1), 89-112.

[3] Aschauer, A. (1989), "Is Public Expenditure Productive?," Journal of Monetary Economics, Vol. 23, 177-200.

[4] AT Kerney (2003), FDI Confidence Index, Global Business Policy Council.

[5] Baltagi, B. H. (2005), Econometric Analysis of Panel Data (Third Edition), John Wiley \& Sons, West Sussex, U.K.

[6] Baltagi, B. H. And Q. Li (1992), "A Note on the Estimation of Simultaneous Equations with Error Components," Econometric Theory, Vol. 8, 113-119.

[7] Balasubramanyam, V N, M. Salisu, and D. Sapsford (1996), "Foreign Direct Investment and Growth in EP and IS Countries," Economic Journal, Royal Economic Society, Vol. 106(434), 92-105, January.

[8] Barro, R.J. and X. Sala-I-Martin (1995), Economic growth, McGraw Hill.

[9] Benhabib, J and M. Spiegel (1994), "The role of human capital in economic development: Evidence from aggregate cross-country data," Journal of Monetary Economics 34, 143-173.

[10] Blanchard, O.J. And F. Giavazzi (2004), "Improving the SGP Through a Proper Accounting of Public Investment," CEPR Discussion Papers 4220, C.E.P.R. Discussion Papers, London.

[11] Blomstrom, M. and H. Persson (1983), "Foreign investment and spillover efficiency in an undeveloped country: Evidence from the Mexican manufacturing industry." World Development Report, 11, 493-501.

[12] Borensztein, E., J. De Gregorio, and J. Lee (1995), "How does foreign direct investment affect economic growth?, " NBER working paper No.5057. 
[13] Calderon, C. and L. Serven (2004), "The Effects of Infrastructure Development on Growth and Income Distribution," World Bank Policy Research Working Paper 3400, The World Bank, Washington D.C.

[14] Campos, N. F. And Y. Kinoshita (2003), "Why Does FDI Go Where it Goes? New Evidence from the Transition Economies, " IMF Working Papers, 03/228, International Monetary Fund.

[15] Durham, B. (2004), "Absorptive capacity and the effects of foreign direct investment and equity foreign portfolio investment on economic growth," European Economic Review vol. 48(2), 285-306.

[16] Easterley, W. and S. Rebelo (1993), "Fiscal Policy and Economic Growth: An Empirical Investigation," Journal of Monetary Economics 32(3), 417-458.

[17] Easterly, W. and S. Rebelo (1994), "Technological Capability and firm efficiency." Working Paper \#11-94-25, The Pennsylvania State University.

[18] Easterly, W. and L. Serven, (Eds.) (2003), The Limits of Stabilization, Infrastructure, Public Deficits, and Growth in Latin America, Stanford University, and The World Bank.

[19] Findlay, R. (1978), "Relative backwardness, direct foreign investment and the transfer of technology: A simple dynamic model," Quarterly Journal of Economics, 92, 1-16.

[20] Girma, S. (2005), "Absorptive Capacity and Productivity Spillovers from FDI: A Threshold Regression Analysis," Oxford Bulletin of Economics and Statistics, 67, 281-306.

[21] Grossman, G. M. and E. Helpman (1991), Innovation and Growth in the Global Economy. The MIT Press.

[22] Haddad, M. And A. Harrison (1993), "Are there positive spillovers from direct foreign investment?: Evidence from panel data for Morocco," Journal of Development Economics 42, 51-74.

[23] International Monetary Fund (2004), "Public Investment and Fiscal Policy," SM/04/93, International Monetary Fund. 
[24] Keller, W. (1995), "Trade and the Transmission of Technology." mimemo, Department of Economics, University of Wisconsin-Madison.

[25] Keller, W. (1996), "Absorptive capacity: on the creation and acquisition of technology in development," Journal of Development Economics 49, 199-227.

[26] Khan, M. And M.S. Kumar (1997), "Public and Private Investment and The Growth Process in Developing Countries," Oxford Bulletin of Economics and Statistics, Vol. 59, No. 1, 69-88.

[27] Kinoshita, Y. (2001), "R\&D and Technology Spillovers via FDI: Innovation and Absorptive Capacity." William Davison Institute working paper 349, University of Michigan Business School.

[28] Kohpaiboon, A. (2002), "Foreign Trade Regime and FDI-Growth Nexus : A Case Study of Thailand," Departmental Working Papers 2002-05, Australian National University, Economics RSPAS.

[29] Koкko, A. (1992), Foreign Direct Investment, Host Country Characteristics, and Spillovers. The Economic Research Institute, Stockholm.

[30] Koкko, A. (1994), "Technology, market characteristics, and spillovers," Journal of Development Economics .

[31] Kokko, A., R. Tansini, And M. C. Zejan (1996), "Local technological capability and productivity spillovers from FDI in the Uruguayan manufacturing sector," The Journal of Development Studies, 32, 602-611.

[32] Kumar, N. (2001), "Infrastructure Availability, Foreign Direct Investment Inflows and Their Export-Orientation: A Cross-Country Exploration,"

[33] Peri, G. And D. Urban (2004), "Catching-Up to Foreign Technology? Evidence on the "Veblen-Gerschenkron" Effect of Foreign Investments." NBER working paper 10893.

[34] Romp, W. And J. DE HaAn (2005), "Public Capital and Economic Growth: A Critical. Survey." European Investment Bank, EIB Papers Vol. 10 No. 1.

[35] United Nations, Industrial statistical yearbook (1996).

[36] Wheeler, D. And A. Mody (1992), "International Investment Location Decisions: The Case of U.S. Firms," Journal of International Economics 33, 57-76. 
Figure 1: FDI, Infrastructure, and Growth

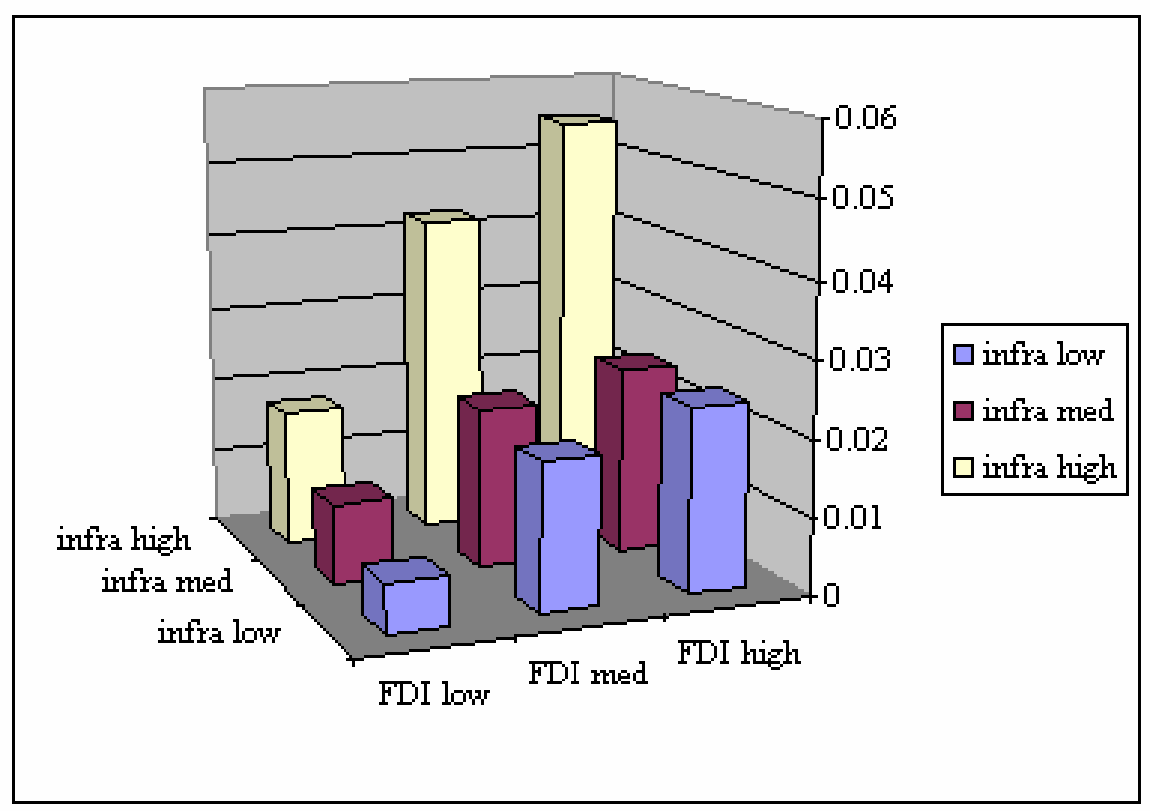


Figure 2: Simulations
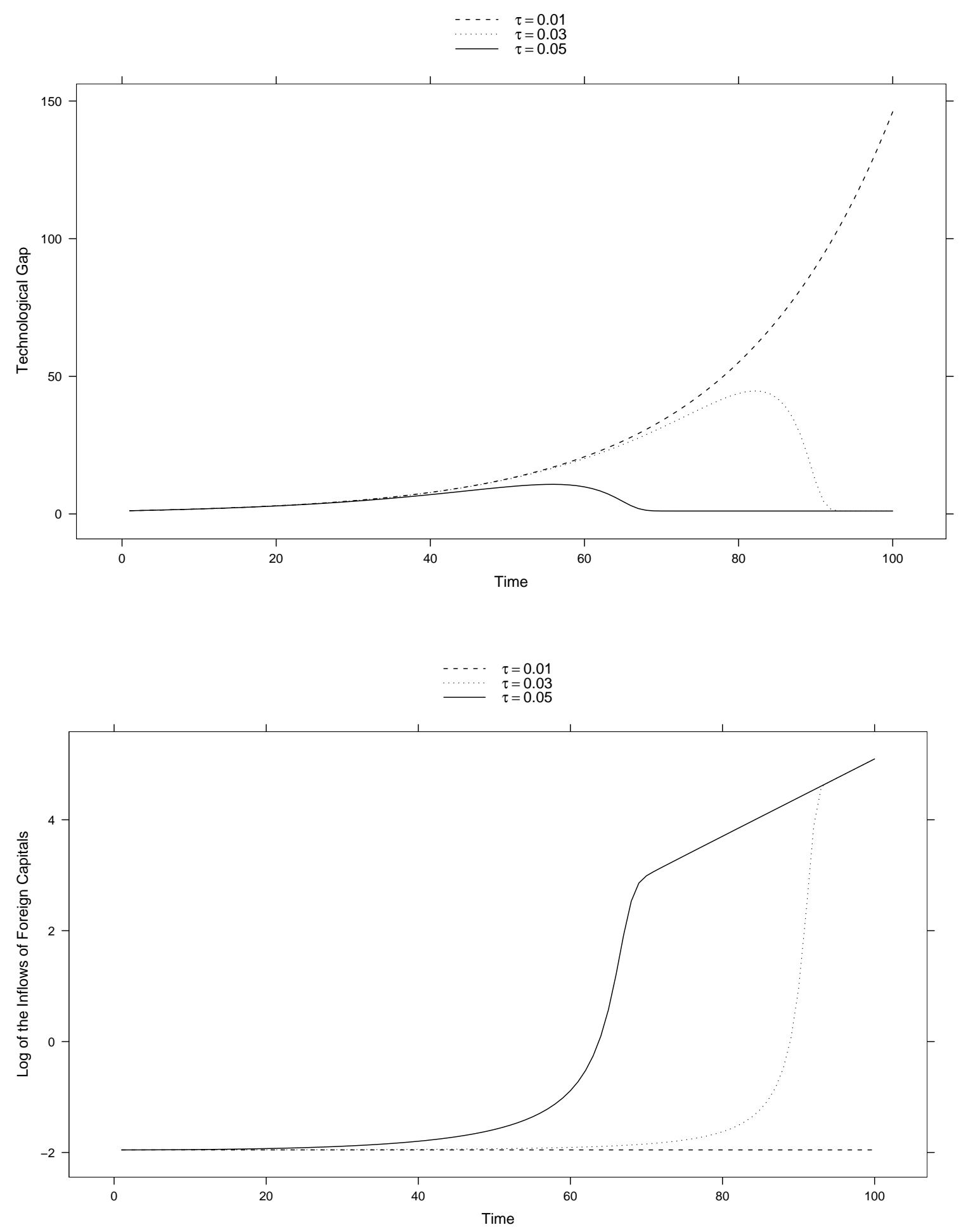

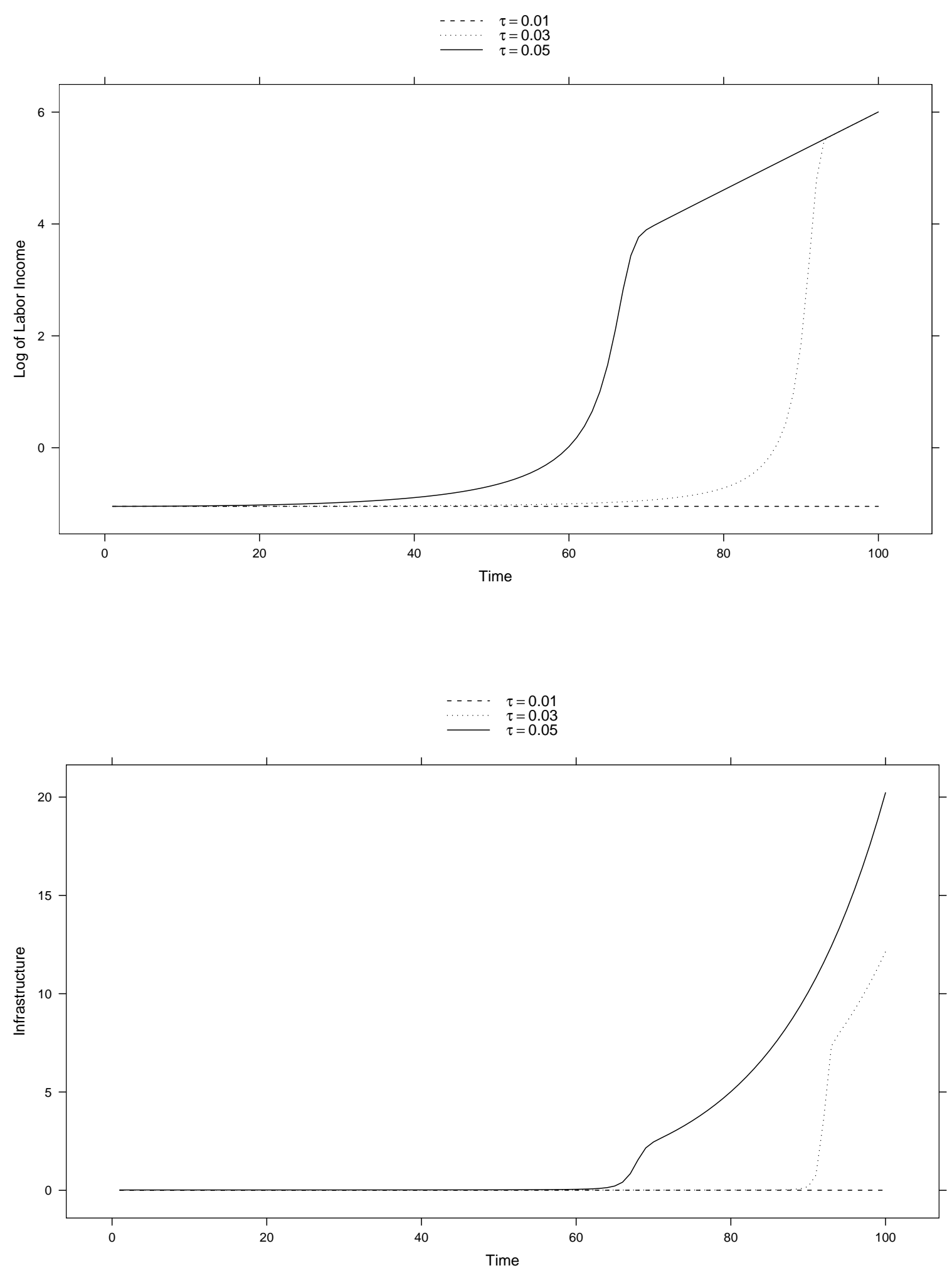

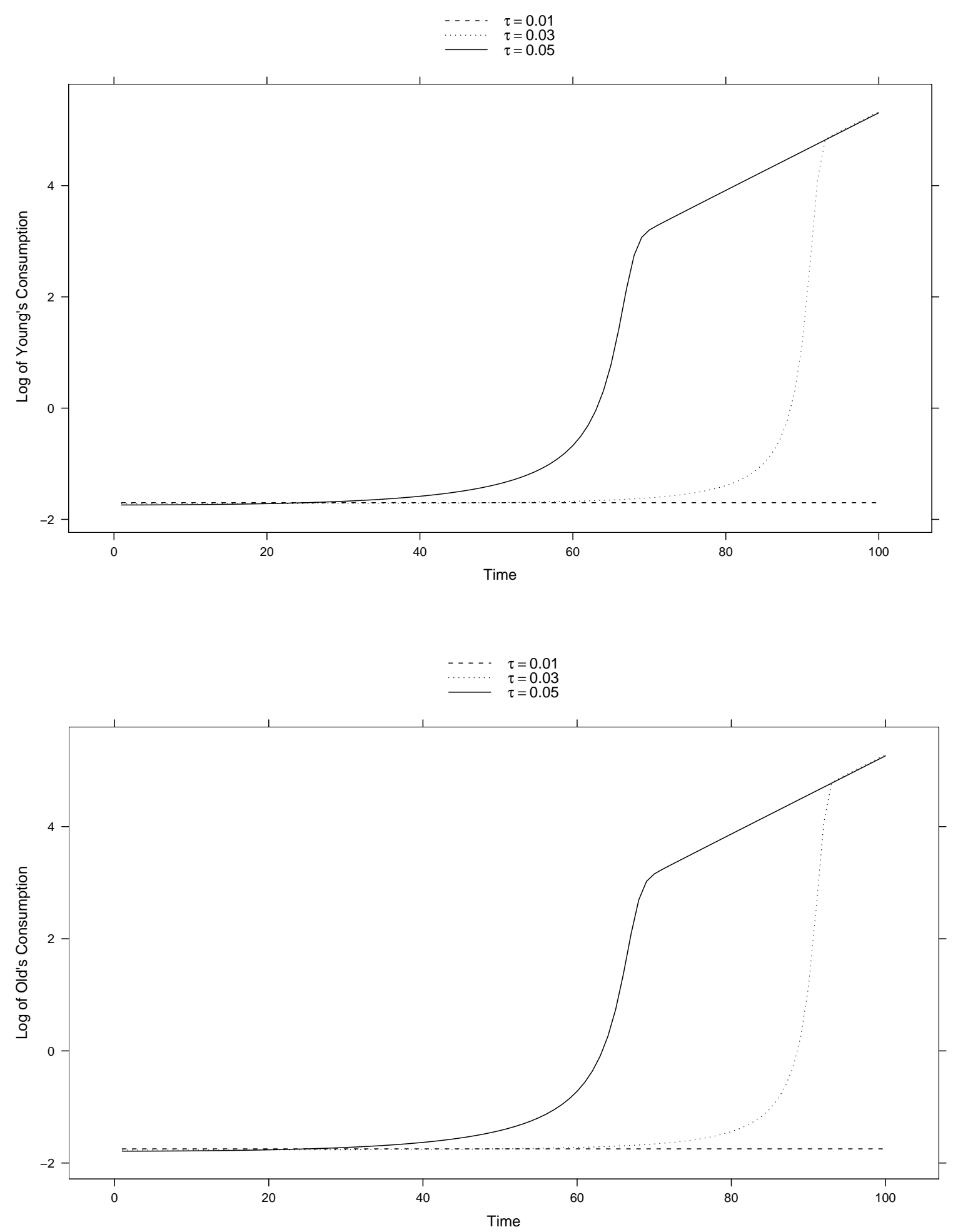
Table 1. FDI, Absorptive Capacity, and Growth ( 5-year panel of 1971-2000)

\begin{tabular}{|c|c|c|c|c|c|c|}
\hline & (1)OLS & (2)OLS & (3)GLS & (4)Within & (5)Between & (6)MLE \\
\hline \multirow[t]{2}{*}{$\log (G D P 0)$} & -0.126 & -0.179 & -0.179 & & -0.124 & -0.179 \\
\hline & $(4.61)^{* *}$ & $(6.12)^{* *}$ & $(5.26)^{* *}$ & & $(2.43)^{*}$ & $(5.29) * *$ \\
\hline \multirow[t]{2}{*}{ Pop growth } & -0.009 & -0.006 & 0.003 & 0.000 & -0.044 & 0.004 \\
\hline & $(0.59)$ & $(0.40)$ & $(0.19)$ & $(0.01)$ & $(1.41)$ & $(0.28)$ \\
\hline \multirow[t]{2}{*}{ Schooling } & 0.117 & 0.109 & 0.093 & -0.134 & 0.275 & 0.089 \\
\hline & $(2.72)^{* *}$ & $(2.66)^{* *}$ & $(2.19)^{*}$ & $(1.92)$ & $(3.17)^{* *}$ & $(2.08)^{*}$ \\
\hline \multirow[t]{2}{*}{ Gov't consumption } & -0.002 & -0.003 & -0.003 & -0.005 & 0.002 & -0.003 \\
\hline & $(1.50)$ & $(2.03)^{*}$ & $(1.80)$ & $(2.48)^{*}$ & $(0.68)$ & $(1.86)$ \\
\hline \multirow[t]{2}{*}{ Log (blkmrkt) } & -0.010 & -0.009 & -0.010 & -0.008 & -0.012 & -0.010 \\
\hline & $(1.44)$ & $(1.34)$ & $(1.39)$ & $(0.98)$ & $(0.78)$ & $(1.45)$ \\
\hline \multirow[t]{2}{*}{ FDI } & -1.961 & -0.864 & -2.115 & -7.951 & 0.633 & -2.400 \\
\hline & $(1.16)$ & $(0.53)$ & $(1.17)$ & $(3.25)^{* * *}$ & $(0.19)$ & $(1.28)$ \\
\hline \multirow[t]{2}{*}{ FDI*Schooling } & -4.990 & -4.179 & -3.295 & 2.771 & -16.398 & -3.094 \\
\hline & $(2.26)^{*}$ & $(1.99)^{*}$ & $(1.62)$ & $(1.20)$ & $(3.11)^{* *}$ & $(1.55)$ \\
\hline \multirow[t]{2}{*}{ Infra } & 0.011 & 0.048 & 0.049 & 0.024 & -0.026 & 0.049 \\
\hline & $(0.49)$ & $(2.08)^{*}$ & $(1.92)$ & $(0.64)$ & $(0.53)$ & $(1.97)^{*}$ \\
\hline \multirow[t]{2}{*}{ FDI*Infra } & 1.912 & 1.517 & 1.631 & 1.314 & 4.127 & 1.651 \\
\hline & $(2.80)^{* *}$ & $(2.33)^{*}$ & $(2.45)^{*}$ & $(1.54)$ & $(2.64)^{*}$ & $(2.57)^{*}$ \\
\hline Period dummies & No & Yes & Yes & Yes & & Yes \\
\hline Observations & 170 & 170 & 170 & 170 & 42 & 170 \\
\hline R-squared & 0.28 & 0.37 & & 0.19 & 0.65 & \\
\hline Number of CS & & & 42 & 42 & 42 & 42 \\
\hline
\end{tabular}

Notes:

The dependent variable is average real per capita GDP growth over each five-year period. All regressions include a constant term. Parentheses are t-statistics. *, ** denote $5 \%$ and $1 \%$ level significance, respectively. 
Table 2. FDI, growth and alternative infrastructure variables (5-year panel of 1971-2000)

\begin{tabular}{lccc} 
& Power generation & Roads & Principle \\
\hline Ln(GDP0) & -0.092 & -0.073 & -0.121 \\
Population growth & $(2.78)^{* *}$ & $(3.31)^{* *}$ & $(3.80)^{* *}$ \\
Schooling & -0.003 & -0.001 & 0.005 \\
& $(0.21)$ & $(0.04)$ & $(0.35)$ \\
Gov't consumption & 0.101 & 0.065 & 0.067 \\
& $(2.38)^{*}$ & $(1.78)$ & $(1.47)$ \\
Ln(1+blkmrkt) & -0.002 & -0.002 & -0.002 \\
FDI & $(1.14)$ & $(1.28)$ & $(1.36)$ \\
& -0.015 & -0.015 & -0.014 \\
FDI*schooling & $(2.01)^{*}$ & $(1.99)^{*}$ & $(1.88)$ \\
& 3.101 & -0.864 & 1.680 \\
Infrastructure & $(1.20)$ & $(0.46)$ & $(0.74)$ \\
& -1.330 & 0.825 & -0.620 \\
FDI*infrastructure & $(0.67)$ & $(0.55)$ & $(0.31)$ \\
Period dummies & -0.002 & 0.030 & 0.040 \\
Observations & $(0.06)$ & $(1.48)$ & $(1.19)$ \\
Number of CS & 1.051 & -0.457 & 0.864 \\
& $(1.41)$ & $(0.78)$ & $(0.95)$ \\
& Yes & Yes & Yes \\
& & & 470 \\
\hline
\end{tabular}

Notes:

The dependent variable is average real per capita GDP growth over each five-year period. All

regressions presented here are generalized least square. All include a constant term. Parentheses are t-statistics. $*$ and $* *$ denote $5 \%$ and $1 \%$ significance, respectively. 
Table 3. FDI, growth and other absorptive capacities (5-year panel for 1971-2000)

\begin{tabular}{|c|c|c|c|c|c|c|c|}
\hline & (1) & (2) & (3) & (4) & (5) & (6) & (7) \\
\hline Ln(GDP0) & $\begin{array}{c}-0.182 \\
(5.51)^{* *}\end{array}$ & $\begin{array}{c}-0.187 \\
(5.16)^{* *}\end{array}$ & $\begin{array}{c}-0.176 \\
(4.96)^{* *}\end{array}$ & $\begin{array}{c}-0.174 \\
(4.88)^{* *}\end{array}$ & $\begin{array}{c}-0.213 \\
(5.38)^{* *}\end{array}$ & $\begin{array}{c}-0.218 \\
(5.66)^{* *}\end{array}$ & $\begin{array}{c}-0.195 \\
(4.97)^{* *}\end{array}$ \\
\hline Population growth & $\begin{array}{l}0.004 \\
(0.25)\end{array}$ & $\begin{array}{c}-0.016 \\
(0.81)\end{array}$ & $\begin{array}{l}-0.015 \\
(0.77)\end{array}$ & $\begin{array}{l}-0.017 \\
(0.85)\end{array}$ & $\begin{array}{l}0.006 \\
(0.40)\end{array}$ & $\begin{array}{l}0.005 \\
(0.34)\end{array}$ & $\begin{array}{l}0.004 \\
(0.28)\end{array}$ \\
\hline Schooling & $\begin{array}{c}0.114 \\
(2.54)^{*}\end{array}$ & $\begin{array}{c}0.093 \\
(2.13)^{*}\end{array}$ & $\begin{array}{c}0.110 \\
(2.50)^{*}\end{array}$ & $\begin{array}{c}0.093 \\
(2.15)^{*}\end{array}$ & $\begin{array}{l}0.084 \\
(1.84)\end{array}$ & $\begin{array}{c}0.091 \\
(2.03)^{*}\end{array}$ & $\begin{array}{c}0.097 \\
(1.98)^{*}\end{array}$ \\
\hline Gov't consumption & $\begin{array}{l}-0.002 \\
(1.60)\end{array}$ & $\begin{array}{l}-0.003 \\
(1.82)\end{array}$ & $\begin{array}{l}-0.002 \\
(1.29)\end{array}$ & $\begin{array}{l}-0.003 \\
(1.95)\end{array}$ & $\begin{array}{l}-0.003 \\
(1.53)\end{array}$ & $\begin{array}{l}-0.003 \\
(1.73)\end{array}$ & $\begin{array}{l}-0.002 \\
(0.86)\end{array}$ \\
\hline $\operatorname{Ln}(1+\mathrm{blkmrkt})$ & $\begin{array}{l}-0.012 \\
(1.71)\end{array}$ & $\begin{array}{l}-0.013 \\
(1.79)\end{array}$ & $\begin{array}{l}-0.012 \\
(1.63)\end{array}$ & $\begin{array}{l}-0.011 \\
(1.55)\end{array}$ & $\begin{array}{l}-0.007 \\
(0.91)\end{array}$ & $\begin{array}{l}-0.011 \\
(1.54)\end{array}$ & $\begin{array}{l}-0.004 \\
(0.42)\end{array}$ \\
\hline FDI & $\begin{array}{l}-1.335 \\
(0.73)\end{array}$ & $\begin{array}{l}-0.961 \\
(0.34)\end{array}$ & $\begin{array}{l}-0.651 \\
(0.29)\end{array}$ & $\begin{array}{l}-2.525 \\
(1.22)\end{array}$ & $\begin{array}{l}-2.683 \\
(1.31)\end{array}$ & $\begin{array}{r}-1.530 \\
(0.76)\end{array}$ & $\begin{array}{l}2.218 \\
(0.92)\end{array}$ \\
\hline FDI*schooling & $\begin{array}{l}-4.315 \\
(2.03)^{*}\end{array}$ & $\begin{array}{l}-4.400 \\
(2.11)^{*}\end{array}$ & $\begin{array}{l}-4.884 \\
(2.36)^{*}\end{array}$ & $\begin{array}{l}-4.618 \\
(2.25)^{*}\end{array}$ & $\begin{array}{l}-3.017 \\
(1.40)\end{array}$ & $\begin{array}{l}-3.470 \\
(1.66)\end{array}$ & $\begin{array}{l}-4.452 \\
(1.94)\end{array}$ \\
\hline Infrastructure & $\begin{array}{l}0.044 \\
(1.76)\end{array}$ & $\begin{array}{l}0.043 \\
(1.58)\end{array}$ & $\begin{array}{l}0.033 \\
(1.18)\end{array}$ & $\begin{array}{l}0.041 \\
(1.53)\end{array}$ & $\begin{array}{c}0.068 \\
(2.41)^{*}\end{array}$ & $\begin{array}{c}0.064 \\
(2.33)^{*}\end{array}$ & $\begin{array}{c}0.061 \\
(2.03)^{*}\end{array}$ \\
\hline FDI*infrastructure & $\begin{array}{c}2.043 \\
(2.70)^{* *}\end{array}$ & $\begin{array}{c}2.338 \\
(2.91)^{* *}\end{array}$ & $\begin{array}{c}2.635 \\
(3.22)^{* *}\end{array}$ & $\begin{array}{c}1.793 \\
(2.33)^{*}\end{array}$ & $\begin{array}{c}1.713 \\
(1.98)^{*}\end{array}$ & $\begin{array}{c}2.119 \\
(2.67)^{* *}\end{array}$ & $\begin{array}{l}1.106 \\
(1.23)\end{array}$ \\
\hline Openness & $\begin{array}{c}-0.000 \\
(0.43)\end{array}$ & & & & & & \\
\hline FDI*openness & $\begin{array}{l}-0.019 \\
(0.83)\end{array}$ & & & & & & \\
\hline Rule of Law & & $\begin{array}{l}0.006 \\
(0.67)\end{array}$ & & & & & \\
\hline FDI*Rule of Law & & $\begin{array}{l}-0.628 \\
(0.65)\end{array}$ & & & & & \\
\hline Corruption & & & $\begin{array}{l}0.007 \\
(0.93)\end{array}$ & & & & \\
\hline FDI ${ }^{*}$ Corruption & & & $\begin{array}{l}-1.031 \\
(1.42)\end{array}$ & & & & \\
\hline Bureaucracy & & & & $\begin{array}{l}-0.006 \\
(0.44)\end{array}$ & & & \\
\hline FDI*Bureaucracy & & & & $\begin{array}{l}1.314 \\
(1.35)\end{array}$ & & & \\
\hline Liquidity & & & & & $\begin{array}{l}-0.105 \\
(1.28)\end{array}$ & & \\
\hline FDI*liquidity & & & & & $\begin{array}{l}2.717 \\
(0.73)\end{array}$ & & \\
\hline Private credit & & & & & & $\begin{array}{l}-0.007 \\
(0.10)\end{array}$ & \\
\hline FDI* private credit & & & & & & $\begin{array}{l}-2.685 \\
(0.69)\end{array}$ & \\
\hline Stock mrkt cap. & & & & & & & $\begin{array}{l}0.030 \\
(0.63)\end{array}$ \\
\hline FDI*stock mrkt cap & & & & & & & $\begin{array}{l}3.218 \\
(0.90)\end{array}$ \\
\hline Observations & 170 & 163 & 163 & 163 & 152 & 157 & 114 \\
\hline Number of cs & 42 & 40 & 40 & 40 & 41 & 42 & 35 \\
\hline
\end{tabular}


Table 4 FDI, Absorptive capacity, catch-up effect and growth (5-year panel)

\begin{tabular}{lcccc} 
& $(1)$ & $(2)$ & $(3)$ & $(4)$ \\
\hline \multirow{2}{*}{ Population growth } & -0.003 & 0.003 & 0.001 & 0.002 \\
& $(0.19)$ & $(0.21)$ & $(0.10)$ & $(0.14)$ \\
Schooling & 0.026 & 0.037 & 0.086 & 0.090 \\
& $(0.57)$ & $(0.94)$ & $(2.09)^{*}$ & $(2.33)^{*}$ \\
Gov't consumption & -0.002 & -0.002 & -0.002 & -0.003 \\
& $(1.13)$ & $(1.57)$ & $(1.62)$ & $(2.14)^{*}$ \\
Ln(1+ blakmrkt) & -0.012 & -0.008 & -0.008 & -0.009 \\
& $(1.63)$ & $(1.02)$ & $(1.06)$ & $(1.30)$ \\
FDI & -0.895 & -5.538 & -2.999 & 0.369 \\
FDI*schooling & $(0.40)$ & $(2.80)^{* *}$ & $(1.41)$ & $(0.16)$ \\
& 1.392 & 0.862 & -1.636 & -2.441 \\
Infrastructure & $(0.83)$ & $(0.59)$ & $(0.97)$ & $(1.47)$ \\
& -0.004 & 0.005 & -0.018 & 0.021 \\
FDI*(Ymax/Y) & $(0.25)$ & $(0.33)$ & $(1.15)$ & $(1.01)$ \\
FDI*(Ymax/Y)* & -0.021 & & -0.314 & -0.396 \\
infrastructure & $(0.18)$ & & $(2.57)^{*}$ & $(3.27)^{* *}$ \\
Ymax/Y & & 0.230 & 0.335 & 0.261 \\
Period dummies & & $(3.81)^{* *}$ & $(4.79)^{* *}$ & $(3.62)^{* *}$ \\
Observations & & & & 0.011 \\
Number of id & & & & $(2.75)^{* *}$ \\
\hline & & & $Y e s$ & 170 \\
& & & 42 & 42 \\
\hline
\end{tabular}

Notes:

The dependent variable is average real per capita GDP growth over each five-year period. All regressions presented here are generalized least square. All include a constant term. Parentheses are t-statistics. ${ }^{*}$ and $* *$ denote $5 \%$ and $1 \%$ significance, respectively. 
Table 5. FDI, absorptive capacity, and growth (5-year panel)

\begin{tabular}{lcc} 
& $(1)$ G2SLS & $(2)$ EC2SLS \\
\hline \multirow{2}{*}{ Log(GDP0) } & -0.103 & -0.154 \\
& $(1.15)$ & $(4.27)^{* *}$ \\
Pop growth & 0.007 & -0.025 \\
& $(0.11)$ & $(1.23)$ \\
Schooling & 0.355 & 0.217 \\
& $(1.06)$ & $(2.81)^{* *}$ \\
Gov't consumption & -0.004 & -0.003 \\
& $(1.28)$ & $(2.06)^{*}$ \\
Log (blkmrkt) & -0.012 & -0.009 \\
& $(0.80)$ & $(1.26)$ \\
FDI & -3.464 & -7.983 \\
& $(1.43)$ & $(1.52)$ \\
FDI*schooling & -16.715 & -11.242 \\
& $(0.81)$ & $(2.51)^{*}$ \\
Infrastructure & -0.236 & -0.032 \\
& $(1.15)$ & $(0.67)$ \\
FDI*Infrastructure & 1.877 & 5.050 \\
& $(1.56)$ & $(2.67)^{* *}$ \\
Period dummies & Yes & Yes \\
Observations & 157 & 157 \\
Number of CS & 39 & 39 \\
\hline
\end{tabular}

Notes:

The dependent variable is average real per capita GDP growth over each five-year period. G2SLS is generalized two-stage least square and EC2SLS is error-component two-stage least square. All include a constant term. Parentheses are z-statistics. $*$ and $* *$ denote $5 \%$ and $1 \%$ significance, respectively. Instruments variables used for FDI are lagged FDI, corruption, bureaucracy, law, and log of population. 
Table 6. FDI, absorptive capacity, catch-up and growth (5-year panel)

(1)G2SLS

(2)EC2SLS

\begin{tabular}{lcc}
\hline & & \\
Pop growth & $(0.04)$ & -0.014 \\
& 0.156 & $(0.64)$ \\
Schooling & $(0.72)$ & 0.181 \\
& -0.006 & $(2.73)^{* *}$ \\
Gov't consumption & $(2.57)^{*}$ & -0.005 \\
& -0.010 & $(3.22)^{* *}$ \\
Log(blkmrkt) & $(0.89)$ & -0.010 \\
& 13.967 & $(1.20)$ \\
FDI & $(1.02)$ & 13.778 \\
& -8.089 & $(2.84)^{* *}$ \\
FDI*schooling & $(0.54)$ & -9.680 \\
& 0.026 & $(2.31)^{*}$ \\
Infrastructure & $(0.77)$ & 0.021 \\
& -1.668 & $(1.00)$ \\
FDI*(Ymax/Y) & $(2.81)^{* *}$ & -1.374 \\
& 0.371 & $(4.94)^{* *}$ \\
FDI*(Ymax/Y)* & $(1.12)$ & 0.354 \\
Infrastructure & 0.037 & $(2.34)^{*}$ \\
Ymax/Y & $(3.45)^{* *}$ & 0.031 \\
& Yes & $(4.00)^{* *}$ \\
Period dummies & 157 & Yes \\
Observations & 39 & 157 \\
Number of CS & & 39 \\
\hline
\end{tabular}

Notes:

The dependent variable is average real per capita GDP growth over each five-year period. G2SLS is generalized two-stage least square and EC2SLS is error-component two-stage least square. All include a constant term.

Parentheses are z-statistics. * and ** denote 5\% and $1 \%$ significance, respectively. Instruments variables used for FDI are lagged FDI, corruption, bureaucracy, law, and log of population. 


\section{DAVIDSON INSTITUTE WORKING PAPER SERIES - Most Recent Papers}

The entire Working Paper Series may be downloaded free of charge at: www.wdi.umich.edu

CURRENT AS OF 11/8/06

\begin{tabular}{|c|c|c|}
\hline Publication & Authors & Date \\
\hline $\begin{array}{l}\text { No. 845: On the Role of Absorptive Capacity: FDI Matters to } \\
\text { Growth }\end{array}$ & Yuko Kinishita and Chia-Hui Lu & Aug 2006 \\
\hline No. 844: Current Account Sustainability in Selected Transition Countries & Aleksander Aristovnik & Nov 2006 \\
\hline $\begin{array}{l}\text { No. 843: Policy, Economic Federalism \& Product Market Entry: The } \\
\text { Indian Experience }\end{array}$ & $\begin{array}{l}\text { Sumon Bhaumik, Shubhashis } \\
\text { Gangopadhyay and Shagun } \\
\text { Krishnan }\end{array}$ & Nov 2006 \\
\hline No. 842: Price Mobility of Locations & Konstantin Gluschenko & Oct 2006 \\
\hline $\begin{array}{l}\text { No. 841: The Role of Foreign Direct Investment in the Firm Selection } \\
\text { Process in a Host Country: Evidence from Slovenia }\end{array}$ & Katja Zajc Kejzar & Sept 2006 \\
\hline $\begin{array}{l}\text { No. 840: Family Ownership and Control in Large Firms: The Good, The } \\
\text { Bad, The Irrelevant - and Why? }\end{array}$ & Mike Peng and Yi Jiang & Oct 2006 \\
\hline No. 839: Price Linkages of Russian Regional Markets & Konstantin Gluschenko & Sept 2006 \\
\hline $\begin{array}{l}\text { No. 838: The Effect of Pre-Primary Education on Primary School } \\
\text { Performance }\end{array}$ & $\begin{array}{l}\text { Samuel Berlinski, Sebastian } \\
\text { Galiani and Paul Gertler }\end{array}$ & July 2006 \\
\hline $\begin{array}{l}\text { No. 837: Do Investors Value Insider Trading Laws? International } \\
\text { Evidence }\end{array}$ & Laura Beny & Aug 2006 \\
\hline No. 836: How corruption Hits People When They Are Down & Jennifer Hunt & Aug 2006 \\
\hline No. 835: Mirage at the Bottom of the Pyramid & Aneel Karnani & Aug 2006 \\
\hline $\begin{array}{l}\text { No. 834: Ownership concentration and firm performance: Evidence from } \\
\text { an emerging market }\end{array}$ & Irena Grosfeld & June 2006 \\
\hline $\begin{array}{l}\text { No. 833: Institutions, Networks and Entrepreneurship Development in } \\
\text { Russia: An Exploration }\end{array}$ & Ruta Aidis and Saul Estrin & June 2006 \\
\hline $\begin{array}{l}\text { No. 832: Long \& Short Run Linkages in CEE Stock Markets: } \\
\text { Implications for Portfolio Diversification \& Stock Market Integration }\end{array}$ & $\begin{array}{l}\text { Manolis Syllignakis and Georgios } \\
\text { Kouretas }\end{array}$ & July 2006 \\
\hline $\begin{array}{l}\text { No. 831: Inequality, Fiscal Capacity and the Political Regime } \\
\text { Lessons from the Post-Communist Transition }\end{array}$ & $\begin{array}{l}\text { Christopher J. Gerry and Tomasz } \\
\text { Mickiewicz }\end{array}$ & July 2006 \\
\hline $\begin{array}{l}\text { No. 830: Business Groups in Emerging Markets - } \\
\text { Financial Control and Sequential Investment }\end{array}$ & Christa Hainz & June 2006 \\
\hline $\begin{array}{l}\text { No. 829: Sophisticated Discipline in Nascent Deposit Markets: Evidence } \\
\text { from Post-Communist Russia }\end{array}$ & $\begin{array}{l}\text { Alexei Karas, William Pyle and } \\
\text { Koen Schoors }\end{array}$ & June 2006 \\
\hline $\begin{array}{l}\text { No. 828: Financial Deregulation and Financial Development, and } \\
\text { Subsequent Impact on Economic Growth in the CzechRepublic, Hungary } \\
\text { and Poland }\end{array}$ & Patricia McGrath & June 2006 \\
\hline $\begin{array}{l}\text { No. 827: The Determinants \& Excessiveness of Current AccountDeficits } \\
\text { in Eastern Europe \& the Former Soviet Union }\end{array}$ & Aleksander Aristovnik & June 2006 \\
\hline $\begin{array}{l}\text { No. 826: Privatization with Government Control: Evidence from the } \\
\text { Russian Oil Sector }\end{array}$ & $\begin{array}{l}\text { Daniel Berkowitz and Yadviga } \\
\text { Semikolenova }\end{array}$ & $\begin{array}{l}\text { February } \\
2006\end{array}$ \\
\hline No. 825: Corruption \& Bureaucratic Structure in a Developing Economy & John Bennett and Saul Estrin & $\begin{array}{l}\text { February } \\
2006\end{array}$ \\
\hline No. 824: Regulatory Barriers \& Entry in Developing Economies & John Bennett and Saul Estrin & $\begin{array}{l}\text { March } \\
2006\end{array}$ \\
\hline No. 823: Enterprise Restructuring in Belarus & $\begin{array}{l}\text { Marina Bakanova, Saul Estrin, } \\
\text { Igor Pelipas and Sergei Pukovic }\end{array}$ & May 2006 \\
\hline
\end{tabular}

